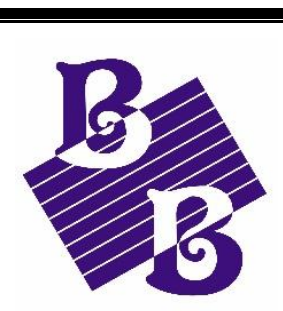

BioBacta

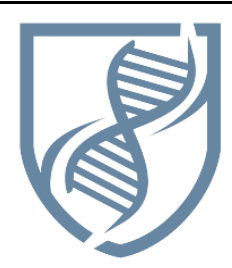

Journal of Bioscience and Applied Research

www.jbaar.org

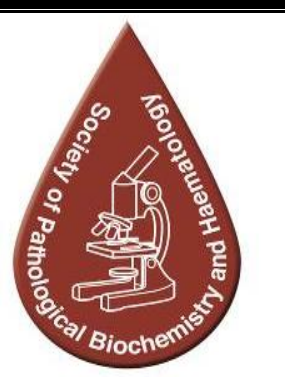

\title{
Study the effect of pheromones on gene expression in the brain of the honeybee Apis mellifera
}

\author{
"Husham Naji Hameed \\ "Department of Biology, College of Education, University of Samarra, Tikrit, Iraq
}

DOI: $10.21608 /$ jbaar.2019.147698

\section{Abstract:}

This research deals with the effect of pheromones, queen mandibular pheromone one gene expression of brain adult for workers honeybee Apis mellifera, these expressions can explain the response behavior induced by pheromones QMP, the impact of gene expression by affecting the movement of workers $A$. mellifera in the colony of honeybees in the case of the presence of the Queen. Queen's absence means the lack of workers as a result of the lack of pheromones (QMP) or the presence of a few compared to the presence of the Queen. The behavior of workers is linked to the existence of pheromones released by the Queen.

Keywords: pheromones, queen mandibular pheromone, gene expression, Apis mellifera, honeybee

\section{Introduction}

Pheromones are chemical substances produced by living organisms in a species to send private messages between members of the same species to suit material sent with the receptor and thus this process is a chemical way transmission of information between members of the same species. [1]. Secrete pheromones from specialized cells found in different areas of the body, either in the form of semi-gaseous substances spread into the atmosphere picked up by members of the other sex of the same type from the air by a special reception center like radar [2].

Pheromones are many types including optical pheromones or radioactive: Alarm pheromone, a type of material secreted by the queen honey bees to cover spaces close to them so that increasingly focus whenever you get close to the source to attract the largest possible number of bees even turn into a radioactive substance so that they form a guide to all members of the cell to gather in a particular place. Trail pheromone, a material produced by the insects when they found food somewhere to attract members of the cell to this place and its food.

pheromones (Queen mandibular pheromone) is a type of pheromones that the queen bee secrete from glands especially to attract males in the seasons of mating pheromones sex (sex attractants) and are pheromones produced by the female for sexual attraction for males or males secrete to attract female insects used as evidence at their location for mating in the mating seasons [3]

The honey bee is an important model for such studies because behavior connects with pheromones 
[4] and has the genome sequence [5]. Understand how neurological and behavioral also requires following the molecular changes that occur in all parts of the brain [6], beneficial mutations in the genes that symbolize a specific protein to form behavioral qualities of honey bees [7]. The most important genes of honey bees Jane secure food and genes protein main royal jelly (Mrjp) in bees workers. choose Jane food security benefits of bee colonies by balancing the number of bees foster parent product and the number of food resources available, willfully infertile women to the secretion of royal jelly proteins to feed their brothers. "The fact that the genes of the protein main royal jelly mrjp subject positive for the selection of a strong show. That genes among infertile women can develop including adapts to the benefit of the Queens lacks the genetic manipulation that would control the behavior of honey bees [8]. The bee is about 15 thousand, most animals then usually two sets of genes: A group comes from the father and the second group comes from the mother, to solve a different number of chromosomes. Gender feminine (and the entry of the Queen) has 32 chromosomes: 16 of them were present in the Queen's eggs, and 16 came with the semen of the male. As the male hatch from an egg is fertilized has 16 chromosomes only and that was in the egg. bees single haploid chromosomes because they have a single set of chromosomes. The sex determination in honey bees through the genotype of the female is called Heterozygous and males are called Homozygous [9]. There is a principle in life that says that the individual tends to work every possibility of inheriting his genes for the next offspring[10]. pheromones affect gene expression in neurons in the brain, particularly concerning genes. [11].

This research aims to show property QMP in the organization of social life in the honey bees and to show its effect on the brain workers A. mellifera gene expression.

\section{Materials and method}

\section{breeding laboratory \\ Rearing.}

Following normal tests, to provide the bees of known age, still, honeycombs containing pupae of the colonies the main source and placed in an incubator

$\left(33{ }^{\circ} \mathrm{C}\right.$, relative humidity $\left.95 \%\right)$.

Attending the cages to the study, the bees collect after 16 hours and placed in a small glass cage area $(10 \times 10) \mathrm{cm}$ and placed (35 Bee/cage) for 8 hours before the start of exposure to the pheromone QMP, provide bee cages with water and food (45\% honey and pollen $45 \%$, water $10 \%$ ). (relative humidity $50 \%$ ) at $33{ }^{\circ} \mathrm{C}$, the pheromone QMP is getting it put a glass slide with the Queen certain. Insects exposed to pheromone QMP on the first day, second, third, and fourth.

\section{Cages study}

Each sample consists of 10 brains (10 brains of bees are taken randomly from each cage containing 35 bees after the entire cage is killed). The heads are analyzed for each time point $(1,2,3$, or 4 days of exposure to QMP). The bee heads are stored at $-80^{\circ}$ $\mathrm{C}$ of liquid nitrogen until explained to prevent any further changes in gene expression [12]. Samples of bees are taken at the same time of day to reduce any variation.

Field studies: Is divided into three honey bee colonies, the colony has retained the original Queen (QR), and the colony without the queen queenless (QL), and the colony was given the third tape that contains property (QMP)[13].

The transfer of the three colonies to a promiscuous different distance of two miles away so as not to return to the cell site of delivery are educated 1500 Bee certain dyes on the dorsal area and put 500 in each of the three colonies, two days later, the bees were collected ( $\mathrm{n}=100 /$ colony) to cutting bees heads, then keep bees in liquid nitrogen. Colonies of the cage containing the queen QMP colonies without Queen QL and a colony containing pheromones QMP 
with slides were compared with each other in the ring design.

\section{Brain anatomy:}

Freeze-dried bee heads explaining to get the brain being anatomy over dry ice to insoluble tissue [14]. Because the compound eyes and ocelli node underneath the esophageal tube often subjected to fracture during the autopsy, still through all this slicing, while the brain remains. Analysis for each time point $(1.2,3$, or 4 days of exposure to the pheromone QMP). The materials used for extraction DNA are shown in table 1,2.

\section{Table 1.Material cat company}

\begin{tabular}{|c|c|c|c|}
\hline & Material & Cat \# & Company \\
\hline 1 & Agarose & 8100.11 & Conda / USA \\
\hline 2 & $\begin{array}{l}\text { Red safe staining } \\
\text { solution }\end{array}$ & 21141 & Intron / Korea \\
\hline 3 & 6X Loading dye & 21161 & Intron / Korea \\
\hline 4 & Ladder 100bp & KK6302 & Kapa /USA \\
\hline 5 & Pre mix pcr & 25025 & Intron / Korea \\
\hline 6 & TBE buffer $10 \mathrm{X}$ & IBS.BT004 & Conda / USA \\
\hline 7 & Primer & --- & Integrated DNA technologies /USA \\
\hline
\end{tabular}

Table2:From head of bee DNA extraction G- spin DNA extraction kit, intron biotechnology, cat.no. 17045 Kit Contents

\begin{tabular}{|l|l|}
\hline Buffer CL & \multicolumn{1}{c|}{ Label } \\
\hline Buffer BL & $25 \mathrm{ml}$ \\
\hline Buffer WA & $25 \mathrm{ml}$ \\
\hline Buffer WB & $40 \mathrm{ml}$ \\
\hline Buffer CE & $10 \mathrm{ml}$ \\
\hline Spin Column / Collection Tube & $20 \mathrm{ml}$ \\
\hline RNase A (Lyophilized powder) & $50 \mathrm{ea}$ \\
\hline Proteinase K (Lyophilized powder) & $3 \mathrm{mg} \times 1$ vial \\
\hline
\end{tabular}

\section{Extraction steps}

Weight $25 \mathrm{mg}$ of a ground tissue sample, and then transfer into $1.5 \mathrm{ml}$ tube using a spatula 2.Then add $200 \mu \mathrm{l}$ Buffer CL, $20 \mu 1$ Proteinase $\mathrm{K}$ and $5 \mu \mathrm{l}$ RNase A Solution into sample tube and mix by vortexing vigorously 3 . Incubate the lysate at $56^{\circ} \mathrm{C}$ (preheated heat block or water bath) for $10 \sim 30 \min 4$. After lysis completely, add $200 \mu \mathrm{l}$ of Buffer BL into the upper sample tube and mix thoroughly5. Then incubate the mixture at $70^{\circ} \mathrm{C}$ for $5 \mathrm{~min} 5$. Centrifuge the sample tube at 13,000 rpm for $5 \mathrm{~min}$ to remove un-lysed tissue particles6. Then carefully transfer $350 \sim 400 \mu 1$ of the supernatant into a new $1.5 \mathrm{ml}$ tube (not provided) 6 . Then add 200 $\mu 1$ of absolute ethanol into the lysate, and mix well by gently inverting $5-6$ times or by pipetting. DO NOT vortex 7. After mixing, briefly centrifuge the $1.5 \mathrm{ml}$ tube to remove drops from the inside of the lid. Carefully apply the mixture from step 6 to the Spin Column (in a $2 \mathrm{ml}$ Collection Tube) without wetting the rim, 
close the cap, and centrifuge at 13,000 rpm for 1 min. Discard the filtrate and place the Spin Column in a $2 \mathrm{ml}$ Collection Tube (reuse) 8 . Also done add $700 \mu$ of Buffer WA to the Spin Column without wetting the rim, and centrifuge for $1 \mathrm{~min}$ at $13,000 \mathrm{rpm}$. Discard the flowthrough and reuse the Collection Tube 9. As well as done add $700 \mu 1$ of Buffer WB to the Spin Column without wetting the rim, and centrifuge for $1 \mathrm{~min}$ at 13,000 rpm. Discard the flowthrough and place the column into a $2.0 \mathrm{ml}$ Collection Tube (reuse), Then again centrifuge for additionally $1 \mathrm{~min}$ to dry the membrane. Discard the flow-through and Collection Tube altogether 10. Place the Spin Column into a new $1.5 \mathrm{ml}$ tube (not supplied), and $30-100 \mu \mathrm{l}$ of Buffer CE directly onto the membrane. Incubate for $1 \mathrm{~min}$ at room temperature and then centrifuge for $1 \mathrm{~min}$ at $13,000 \mathrm{rpm}$ to elute.

\section{Agarose gel electrophoresis of DNA}

Electrophoresis has been done to determine DNA pieces after the process of extraction or to detect the result of the interaction of PCR during the presence of the standard DNA to distinguish the bundle size of the outcome of the interaction of PCR on the Agarose gel Fig 1.

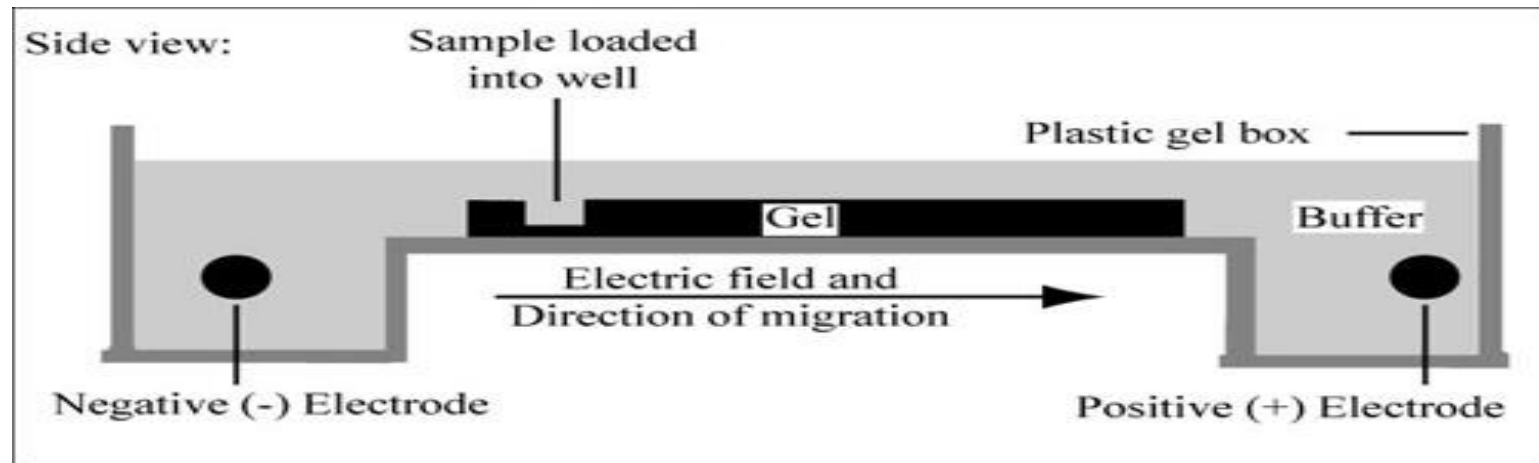

Fig1. Working the electrophoresis system

\section{Prepare the Agarose gel}

According to Sambrook et al (1989), the agarose gel has been made in $1.5 \%$ condensation by melting $1.5 \mathrm{~g}$ of agarose in $100 \mathrm{ml}$ of previously made TBE buffer. Agarose has been heated to boil then left to cool down at $\left(45-50^{\circ} \mathrm{C}\right)$. The gel has been poured into the pour plate in which the plate of agarose support has been prepared after fixing the comb to make holes that would hold the samples. The gel has been poured gently not to make air bubbles and left 30 minutes to cool down. The comb has been removed gently from the solid agarose. The plate has been fixed to its stand in the Electrophoresis horizontal unit represented by the tank used in the Electrophoresis. The tank has been filled with TBE buffer in which covers the gel surface.

\section{Preparation of sample}

$3 \mu 1$ of the processor loading buffer (Intron / Korea) has been mixed with $5 \mu$ l of the supposed DNA to be electrophoresis (loading dye), after the is now to the mixing process, the process of loading holes of the gel. An Electric current of $7 \mathrm{vlc} 2$ has been exposed for 1-2 until the tincture has reached the other side of the gel. The gel has been tested by a source of the UV with $336 \mathrm{~nm}$ after put the gel in a pool contain on $30 \mu 1$ Red safe Nucleic acid staining solution and $500 \mathrm{ml}$ from distilled water.

\section{Result and discussion:}

The effect of QMP on brain gene expression: Regulating pheromones property jaw QMP gene expression in the brain as the leading non-existence of pheromones property QMP female workers to move from one work cell to search for food, then 
follows the pattern is expected: Exposure pheromones property QMP activates genes in the brain associated with the construction of the cell. The study showed that the differences in gene expression between the workers themselves. Compared gene expression in the field of bees in the colonies against the cages shows statistically significant differences in expression in bees differences, extract DNA which can be summarized which shows that the bees in cages show significant differences in expression gene in every day when exposed to pheromones propertyQMP.
KAPA Universal DNA Ladder (cat \# KK6302) The KAPA Universal Ladder Kit is designed for determining the approximate size and quantity of double-stranded DNA on an agarose gel. KAPA Universal Ladder kits contain eighteen DNA fragments (in base pairs): 100, 150, 200, 300, 400, 500, 600, 800,1000, 1200, 1600, 2000, 3000, 4000, 5000, 6000, 8000, and 10000. The KAPA Universal Ladder contains four reference bands (500, 1000, 1600, and 4000) for orientation. Fig 2

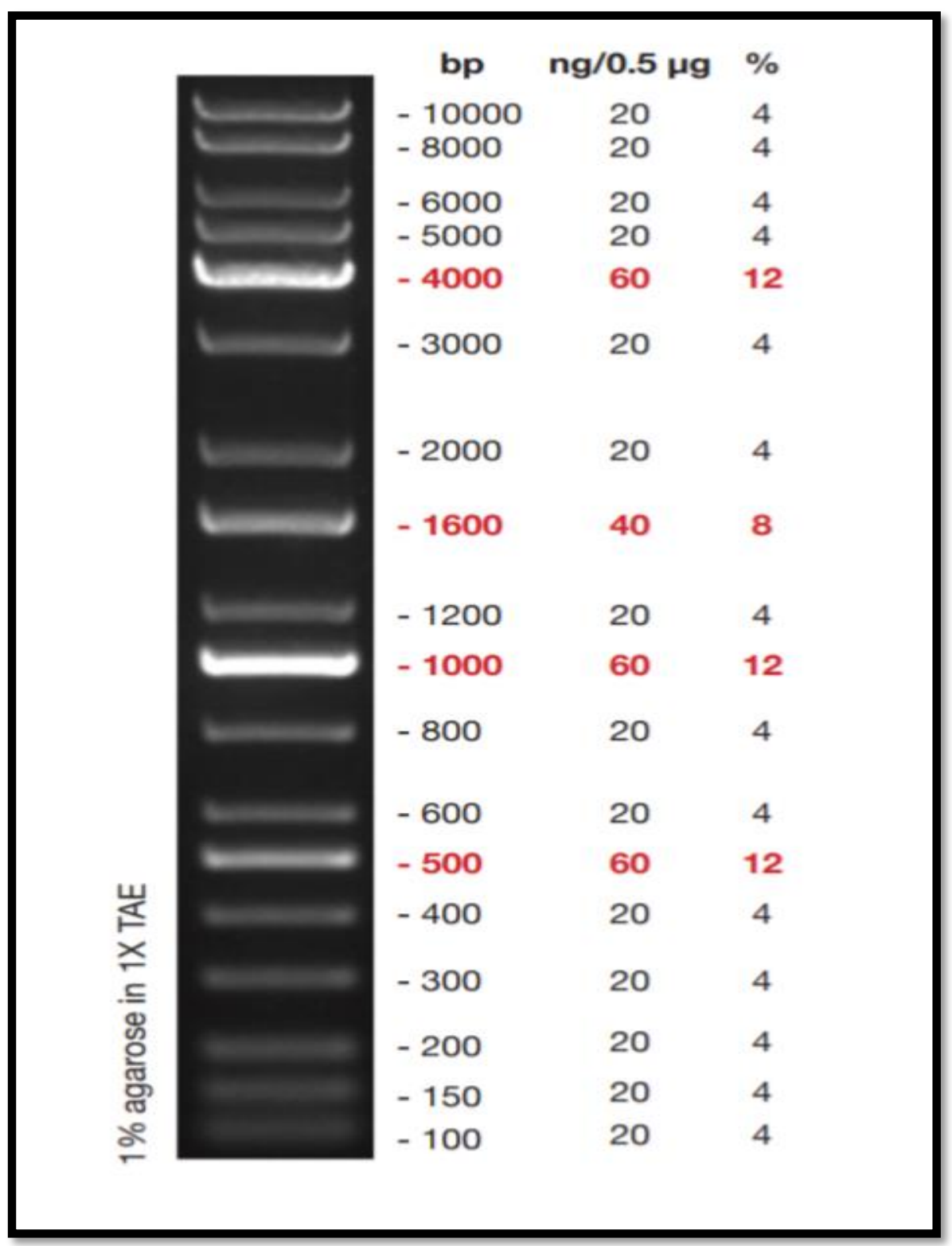




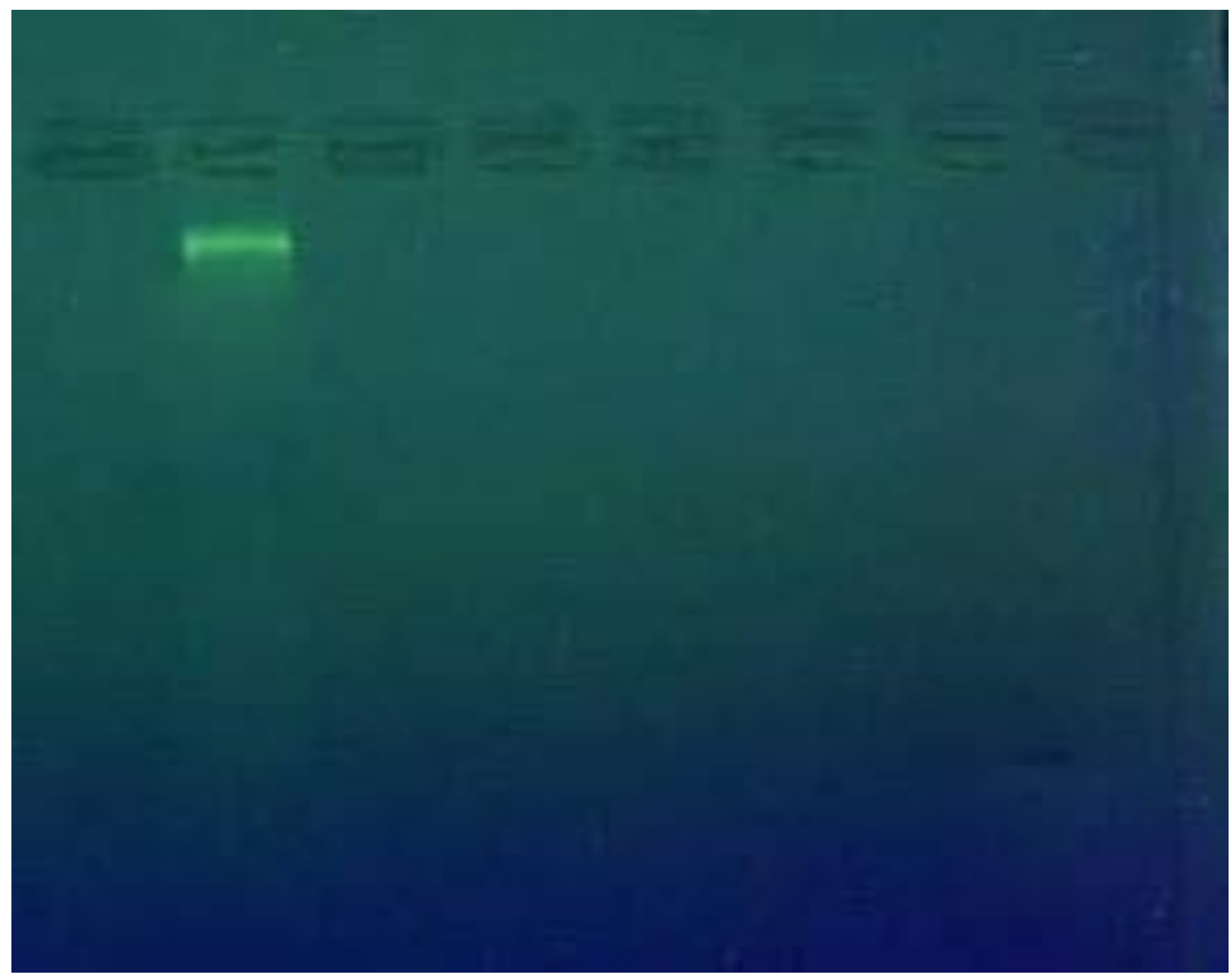

Fig2: Gel electrophoresis of genomic DNA extraction from biopsy, $1 \%$ agarose gel at $5 \mathrm{vol} / \mathrm{cm}$ for 1:15 hours

This study shows that pheromones property QMP cause changes in the expression levels of many genes in the brain of the honey bee, and that these changes are associated with some of the behavioral effects, The discovery of the effects of pheromones property QMP on gene expression both in vitro and in bee colonies in this area, which accounted for pheromones natural environment, QMP, which cause changes in several hundred genes but cause chronic changes in a small subset of all of the genes in the brain, There may be significant overlap in the genes organized by the QMP in the cages and the colonies, but the genetic expression of the colon appears to be altered in the smaller colonies due to the participation of fewer gene. a possible explanation for this is that the gene in response Which diagnoses by primer tab3. A possible explanation for this is that gene in response tab4.

\section{The primers used in the interaction}

The primers were lyophilized, they dissolved in the free dd $\mathrm{H} 2 \mathrm{O}$ to give a final concentration of 100 $\mathrm{pmol} / \mu \mathrm{l}$ as stock solution and keep stock at -20 to prepare $10 \mathrm{pmol} / \mu 1$ concentration as work primer suspended, $10 \mu \mathrm{l}$ of the stock solution in $90 \mu \mathrm{l}$ of the free $\mathrm{ddH} 2 \mathrm{O}$ water to reach a final volume $100 \mu \mathrm{l}$, was investigated by IDT (Integrated DNA Technologies company, Canada). 
Tab3.The specific primer of gene ITS

\begin{tabular}{|c|c|c|c|c|}
\hline Primer & Sequence & $\operatorname{Tm}\left({ }^{\circ} \mathrm{C}\right)$ & GC (\%) & Product size \\
\hline Forward & 5'- TCCGTAGGTGAACCTGCGG -3' & 60.3 & $50 \%$ & $\begin{array}{l}450 \\
\text { base pair }\end{array}$ \\
\hline Reverse & 5' TCCTCCGCTTATTGATATGC-3' & 57.8 & $41 \%$ & \\
\hline
\end{tabular}

Tab4.The specific apis mellifera gene

\begin{tabular}{|c|c|c|c|c|}
\hline Primer & Sequence & $\operatorname{Tm}\left({ }^{\circ} \mathrm{C}\right)$ & GC (\%) & Product size \\
\hline Forward & 5'- TCCGTAGGTGAACCTGCGG -3' & 60.3 & $50 \%$ & $\begin{array}{l}450 \\
\text { base pair }\end{array}$ \\
\hline Reverse & 5' TCCTCCGCTTATTGATATGC-3' & 57.8 & $41 \%$ & \\
\hline
\end{tabular}

There may be considerable overlap in the genes regulated by pheromones property QMP in cages and the colonies, but the gene expression changes appeared in smaller colonies as a result of the participation of the smaller number of genes. This may be because pheromones property jaw QMP issued in the colony quantity of less than pheromones property QMP bees. The optimal condition has identified for (Initial denaturation and annealing) after work several experiments to gain for this condition, the temperature has changed through the work of (Gradient PCR) for all samples to select the optimal condition, and also changed the concentration for DNA template between (1.5$2 \mu \mathrm{l})$ table 5,6.

Diagnosis of Gene.

Tab5: Mixture of the specific interaction for diagnosis gene

\begin{tabular}{|l|l|}
\hline Components & \multicolumn{1}{l|}{ Concentration } \\
\hline Taq PCR PreMix & $5 \mu \mathrm{l}$ \\
\hline Forward primer & 10 picomols $/ \mu \mathrm{l}(1 \mu \mathrm{l})$ \\
\hline Reverse primer & 10 picomols/ $\mu \mathrm{l}(1 \mu \mathrm{l})$ \\
\hline DNA & $1.5 \mu \mathrm{l}$ \\
\hline Distill water & $16.5 \mu \mathrm{l}$ \\
\hline Final volume & $25 \mu \mathrm{l}$ \\
\hline
\end{tabular}


Tab6: The optimum condition of detection gene

\begin{tabular}{|c|c|c|c|c|}
\hline No. & Phase & $\operatorname{Tm}\left({ }^{\circ} \mathrm{C}\right)$ & Time & No. of cycle \\
\hline 1- & Initial Denaturation & $95^{\circ} \mathrm{C}$ & $5 \mathrm{~min}$. & 1 cycle \\
\hline 2- & Denaturation -2 & $95^{\circ} \mathrm{C}$ & $\sec 45$ & \multirow{3}{*}{35 cycle } \\
\hline 3- & Annealing & $58^{\circ} \mathrm{C}$ & $\sec 45$ & \\
\hline 4- & Extension-1 & $72^{\circ} \mathrm{C}$ & $45 \mathrm{sec}$ & \\
\hline 5- & Extension -2 & $72^{\circ} \mathrm{C}$ & $7 \mathrm{~min}$. & 1 cycle \\
\hline
\end{tabular}

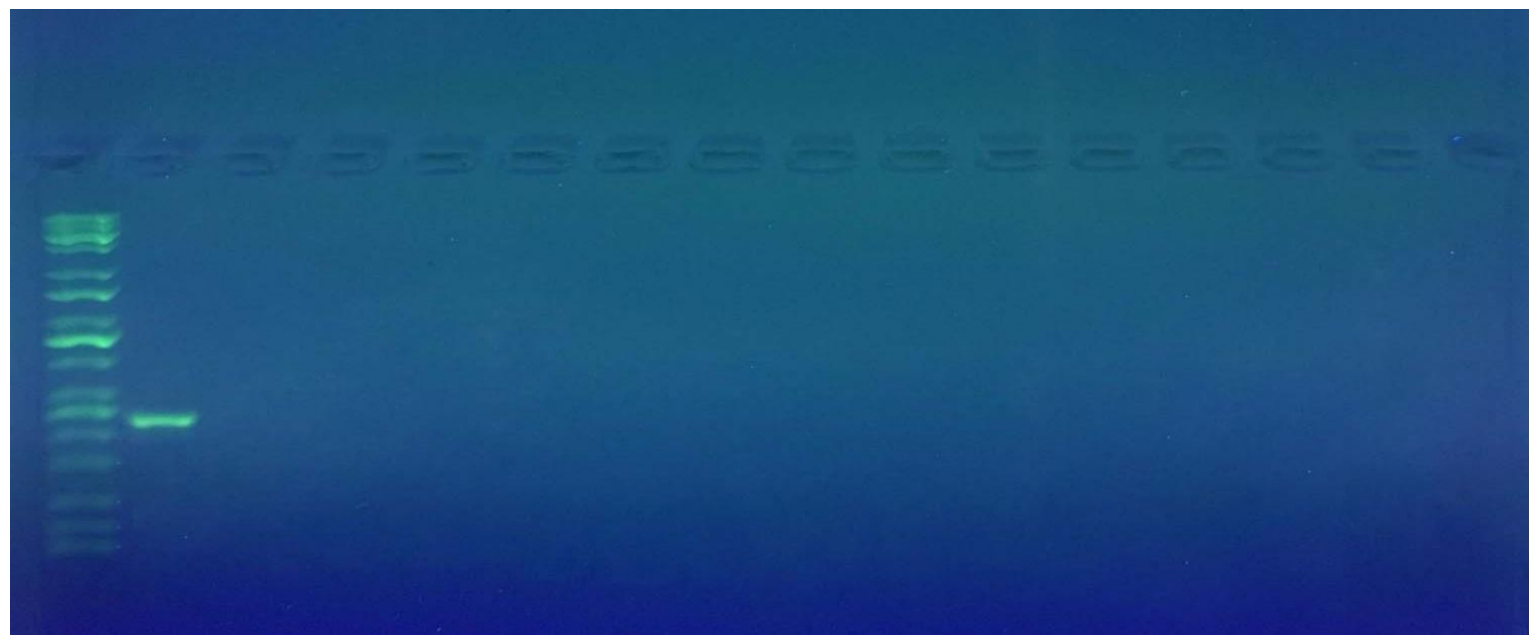

Fig3. PCR product the band size 450bp. The product was electrophoresis on $2 \%$ agarose at $5 \mathrm{volt} / \mathrm{cm}^{2} .1 \mathrm{x}$ TBE buffer for 1:30 hours. N: DNA ladder (100).

These data were compared with results from a previous study (14) the study showed a similarity in gene expression among female workers themselves This study agrees with [16] which explained the effects of pheromones property QMP appear on gene expression in the brain over time. The results of the current study are consistent with[17]. The study which explains These genes may just need to work to produce the necessary pheromone queen response, for example, bees raised in different circumstances of exposure to the pheromone Queen differences may appear clear, this is due to the dynamic nature of the response to the pheromone Queen QMP may be related to the fact that the olfactory system honeybees are still evolving during the first few days of adult life. The results of this study were compared with a study [18]. which showed that the QMP released in the colony is less than the QMP in the bee cages. This may be because the environment has affected the colony.

\section{References:}

[1]-. Wyatt, T.D. (2003). Pheromones and Animal Behaviour: Communication by Smell and Taste. Cambridge: Cambridge University Press.

[2]-Huang, Z.-Y., Winston, M. L. \& Robinson, G. E. (1998) J. Insect Physiol. 44, 685-692

[3]- Winston, M. L. (1987) The Biology of the Honey Bee (Harvard Univ. Press, Cambridge, 
[4]- Le Conte, Y., Costagliola, A.L. (2004) Regulation of behavioral maturation by a primer pheromone produced by adult worker honey bees. Proc Natl Acad Sci USA 101, 1755917564.

[5]-.Gary, N.E. (1992) Activities and behavior of honey bees. In The Hive and the $H$ honey bee

(Dadant and Sons, ed.), pp. 269-274

[6]-Shannon, M., Hamilton, A. T., Gordon, L., Branscomb, E. \& Stubbs, L. (2003) Genome Res. 13, 1097-1110

[7]- Kucharski, R., Maleszka, J., Foret, S. and Maleszka, R. (2008) Nutritional control of reproductive status in honeybees via DNA methylation. Science 319: 1827-1830

[8]-Kocher, S.D., Richard, F.J., Tarpy, D.R. \& Grozinger, C.M. (2008) Genomic analysis of post-mating changes in the honey bee queen (Apis mellifera). BMC Genomics 9, 232.

[9]- Kurtovic, A., Widmer, A. \& Dickson, B.J. (2007) A single class of olfactory neurons mediates behavioral responses to a Drosophila sex pheromone. Nature 446, 542-546.

[10]- Townsend, J. P. \& Hartl, D. L. (2002) Genome Biol. 3, 0071.1-0071.6.

[11]- 11.Xu, Q., Zou, Q., Zheng, H., Zhang, F. (2011) Three heat shock proteins from Spodoptera exigua: Gene cloning, characterization. Biochem Mol Biol 159: 92-102
[12]- Kunieda, T. and Kubo, T. (2004) In vivo gene transfer into the adult honeybee brain by using electroporation. Biochem Biophys Res Commun 318: 25-31

[13]-.Ledoux, M. N., Winston, M. L., Higo, H. A., Keeling, C. I., Slessor, K. N. \& Le Conte, Y. (2001) Insectes Soc. 48, 14-20.

[14]-. Katzav-Gozansky, T., Soroker, V., Ibarra, F., Francke, W. and Hefetz, A. (2001) Dufour's gland secretion of the queen honeybee Apis mellifera, Behav Ecol Sociobiol 51: 76- 86.

[15]-.Kucharski, R., Maleszka, J., Foret, S. and Maleszka, R. (2008) Nutritional control of reproductive status in honeybees via DNA methylation. Science 319: 1827- 1830.

[16]-.Slessor, K.N., Winston, M.L. \& Le Conte, Y. (2005) Pheromone communication in the honeybee (Apis mellifera L.). J Chem Ecol 31, 2731-2745.

[17]- Leoncini, I., Le Conte, Y., Costagliola, G., Plettner, E.. (2004) Regulation of behavioral maturation by a primer pheromone produced by adult worker honey bees. Proc Natl Acad Sci USA 101, 17559-17564.

[18]-.Kocher, S.D., Richard, F.J., Tarpy, D.R. \& Grozinger, C.M. (2008) Genomic analysis of post-mating changes in the honey bee queen (Apis mellifera). BMC Genomics 9, 232. 